\title{
A SIAD ACHIEVEMENT BASED ON THE COLLECTION OF THE INDUSTRY COSTS*
}

\author{
Cezarina Adina TOFAN, Lecturer Ph.D. \\ Spiru Haret University, Faculty of Accounting and Finance, Câmpulung Muscel \\ postdoctoral student, Institute of National Economy-Romanian Academy \\ Email: adina.tofan@spiruharet.ro
}

\begin{abstract}
In modern market economy, organizations have to take decisions in a flexible, dynamic manner. In the economic environment, the relationship between product-market and competition is becoming more and more complex, as the socio-economic environment itself becomes more diversified and complex. Thereby, in order to be efficient, the management has to rely not only on chance and inspiration but especially on scientific methods designed to resolve dilemmas and multiple choice situations. The decision-making process represents an complex sum of activities regarding the collection, processing and selection of information. The information becomes a valuable asset for the organization if it is obtained and used in real-time, therefore the decision making process is highly dependent on complex, operational and qualitative information.
\end{abstract}

Keywords: assisted decision, cost centres, computer system, decision analysis, decision making, data processing

JEL Classification: $\mathrm{M}_{10}, \mathrm{M}_{11}, \mathrm{M}_{15}, \mathrm{C}_{8}$

\section{Introduction}

Structuring of the business activity on the centre of responsibility has become a priority in the customer satisfaction and achievement of a profitable activity.

Considering that the prediction, collection and control of the expenditures, incomes and results on the responsibilities centres represents a possible way of improving the decision support of the designing and production of the models, moulds and other related products and services.

Organization of the budgeting, evidence accounting and the cost calculation on the responsibility centres has the following advantages:

- Improve the information quality on the costs and results

- Impose solutions for using the production capacity

- A real promoting of the responsibility principle.

* This paper has been financially supported within the project entitled "Horizon 2020 Doctoral and Postdoctoral Studies: Promoting the National Interest through Excellence, Competitiveness and Responsibility in the Field of Romanian Fundamental and Applied Scientific Research", contract number POSDRU/159/1.5/S/140106. This project is cofinanced by European Social Fund through Sectoral Operational Programme for Human Resources Development 2007-2013. Investing in people! 
Thus, in the designing and production of the models, moulds for metal and metal carbides are used two cost carriers, one of them as intermediate character represented by the centre costs and other as final character, represented by the customer order.

\section{Methodology and method}

Methodology of the implementation of the business responsibility centres can be accomplished in three phases (Tascovici D., Dragomir R., Isbăşoiu E., Zărnescu O.M., 2013, p. 52-53): $(R C)$

The first phase - the preparation phase of the responsibility centres structure

1.1. Defining RC areas on the enterprise organizational structure

1.2. Knowing the areas and activities that generate costs

1.3. Determination of the unit cost

The second phase - the preparation phase of the information database on the responsibility centres

2.1. Development and introduction the cost-tracking system on the RC

2.2. Creation of the unit costs for the products and services

2.3. Establish the allocation criteria and calculating the absorption rates of the indirect expenditure.

The third phase - the phase of information using through a decision supports system based on the costs, expenses and other financial indicators by the business managers

3.1. Defining the responsibilities for the costs activities

3.2. Reasons for decision-making process

3.3. Analysis and using the information about the costs in a computer system.

In what follows, I detail the methodology for implementation of the responsibility centres. $(R C)$

The first phase - the preparation phase of the responsibility centres structure

The efficiency of the budgeting organization, accounting and the cost calculation on the responsibility centre depends by the fair determining of those.

An important role in the proper organization of the responsibility centres is: the specific of the enterprise's activity, thus is the subject of the business, the production technological features and the organizational structure.

Thus, in all cases, in terms of the organizational and functional structure, the enterprise is divided by the activity sectors, within their departments, as if in the production sector or the functional services, as in the other sectors and further, the sections are broken down into workshops, machinery, equipment and jobs, and functional services and employment offices, not in all cases, the cost centres as objects of calculation, the overlap with organizational and functional structure of the company (Bragă V., 2010, p. 367).

This is not possible, because not all the costs are accurately identify each element of the organizational and functional structure of the enterprise, and on the 
other hand, their follow-up on each of those elements until the level of the production sites would greatly increase the work volume of recording and calculation. For these reasons, the location of costs incurred in the process of manufacture, are joined more production levels or organizational and functional structural links in a single cost centre at the level of: groups of machines, equipment, production lines, workshops, sections, etc. Thus, it appears the concept of the centre costs, which should not be confused with that of a production site, although there is a close link between them.

\section{Discussion and results}

The centre costs can be defined as the organized expression of the functional and production units within a company where they arise and collect the costs of their activities (Tofan A.C., 2008, p. 38).

At the sharing of the enterprise on the cost centres, it can be considered the boundary in terms of their structure, according to administrative and organizational structure, so a cost centre may include an administrative or organizational structure or it may be formed in particular by structuring the business activities in terms of management and cost calculation. At the restructuring of the business activity on the cost centres it is considered envisaged that it must perform the same operation or group of technological operations, to develop a product, a semi-finished one or to perform a certain task. For this the machinery and equipment are grouped by the way how the operation is performed and by the way of their activities. In terms of production technology features, the cost centres can be very deep and can go up to a machine group or of a large machines, which allows the identification of the production costs on each car part or remain in the manufacturing lines, places where it is developed the self-production phase which includes a number of operations.

Also, at the sharing of the enterprise on the responsibility centres, it must take into account by the possibility of a more precise delimitation of their level of expenditures and results in relation to the objectives which must perform by that centre. If for achieving of the certain goals are interfered activities from the several centres, for those activities, it will be created the cost centres distinct, with the separate budgets.

Regarding the establishment of the cost centres is to establish the optimal number of their appearance in the enterprise, so that it can be a balance between the amounts of information provided the cost information, efficiency and the opportunity of them in decisions making for effective management of business and increasing the accountability of those centres.

When is shared an enterprise on the cost centres it is needed to take into account the possibility to determine more accurately the activity as carried out by them, both in quantity and value, if it is possible, or just value (Tascovici D., Dragomir R., Isbăşoiu E., Zărnescu O.M., 2013, p. 54).

Finally, to establish the cost centres it can be considered the possibility of distribution the expenditures on the command centres for the purpose of calculating individually the unit cost of each order. Depending on the basis of constitution, the 
cost centres which operating like expenses places or like the responsibility centres, are of two kinds:

1. Operating costs centres or actual are those in which runs the technology manufacturing operations, sales operations and the supply, so an activity which can be measured quantitatively and qualitatively accurate. They therefore are constituted in the production activities, supply or sale and investment. For the production activities, the operational centres are divided into: primary, if there are constituted for the basic stations and secondary, if there are constituted for the auxiliary activities. Primary and secondary cost centres are called and the main production centres, respectively, secondary, if there are constituted in the production sectors and, thus, there are based on the production operations.

2. Functional cost centres (Bragă 2010, p. 369) are those in which are carried out the organization activities, leadership and management of the production, supply and sales. Such cost centres may be formed to the production department, the workshop, the supply sector, the administrative sector, the sale sector, the investment sector etc.

In terms of administrative and managerial sector, we consider that a greater insight into the cost centres within its service or even offices, it would provide a really better information on the general administration expenditures, which would increase the efficiency budgetary control and the decision making by the managers, but at the same time, it would lead to increase the costs of execution of budget, accounting and costing that is not matched by the effective control and decision-making.

The functional activity of the cost centres, not always can be measured quantitatively, but sometimes it can be assessed only qualitatively, and the expenses incurred by them does not identify a product, semi-finished, as in the operational centres, but they relate to several operational centres costs, but although they are not identified with the latest, and are therefore indirectly to them, however, there are direct from the first.

Following on this, the functional centres will reflect those costs which may not be broken by any criteria in the operational centres, but which are still in the production cost. Individualization of the production expenses on the cost centres that they incurred is to change their character from the indirect costs, common to all departments, for example, in the direct costs of those centres.

Cost centres must be established for all the business activities (Zaman G., Gherasim Z., 2010, p. 11).

All cost centres from a business form the enterprise as a whole.

To track the labour force and material consumption for each command within each cost centre, we proposed an informatics system that would allow the accounting organization in a single circuit as follows:

- each document representing the consumption of the raw and directly materials related to an order to be accounted using the expense accounts in the accounts plan followed by the command symbol, and in the same time it will be recorded in the post calculation sheet. 
- use of work life as evidenced by payroll (prepared on the timesheets sheets) it will be recorded on each cost centre using the digit symbol of the expense account, but also in the post calculation sheet on each order.

- each document representing the consumption of materials and services necessary to conduct the cost centres activity will be recorded using the symbol of the expenditure account from the accounts plan in each cost centre.

The cost centres will be established as follows for dies and moulds manufacturing activity:

$C_{0}$ - common centre (General Management)

$C_{1}$ - numerical control for using centre

$C_{2}$ - classical using centre

$C_{3}$ - MAP adjusting centre

$\mathrm{C}_{4}$ - modelling centre

$C_{5}$ - technical centre

$\mathrm{C}_{6}$ - quality centre

At the end of each month, it should be compared the expenditure and income planned with the expenditure and income made, establishing: deviations, causes and measures to improve the activity (Tofan A.C., 2008, p. 51).

In a study of the designing and production of models, moulds and other related products and services, has made an application (SIAD), which begins with a dashboard display that allows to the users to express easily their options, such as the reports data, print of the results and calculating the profitability indicators. In achievement of the information application on the project of assisting the financial analysis I chose a dashboard created in Excel, in a unified form, which offers the advantage that any point of application is possible to return to the dashboard.

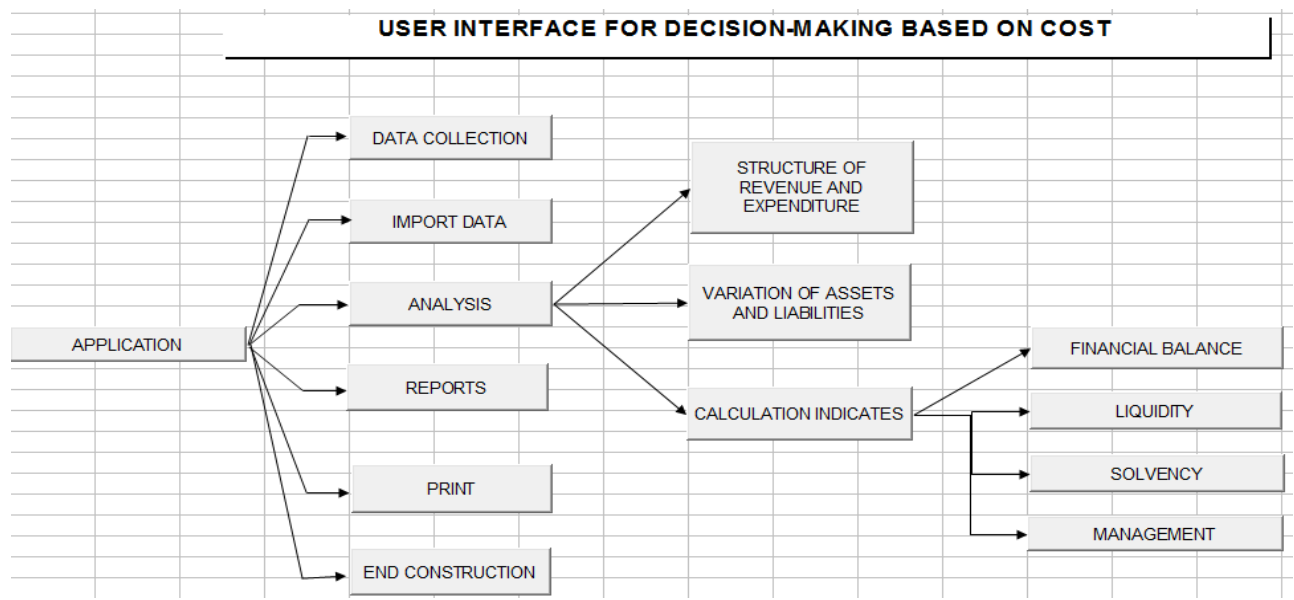

The SIAD dashboard application 
The database component consists of two calculation sheets called Balance and Profit and Loss Account. The sheets are structured according to the standardized forms. The loading is done either by import or by typing directly in the spread sheet data. The work period is 2011-2012.

Advantages of the proposed model: allows the accumulation and follow-up of the expenditure on the expenditure items; saving time and costs; allow their uniform classification and tracking of the deviations; creating the statistics data base for the future period; enable the preparation of the operational information reports to the manager; enable the following of the accumulated expenditure on the each order.

\section{Conclusions}

Through the quantitative analysis aims the numerical evaluation of the probability and impact of each risk on the organization's objectives.

With this method there are represented the decisions and the random events as they are perceived by the decision makers.

In conclusion, the information system is a basic subsystem of the enterprise management, which achieving the multiple functions and presents an accentuated dynamics.

Efficiency of the decision-making is directly proportionate to the nature, quality, quantity, frequency and the volume of information that decider has them at his disposal.

A quality process on the decision-making has influence over the profit, cost and the efficiency of using the product factors. A decision-making involves a great consumption of time, while there are collecting and analysing the information, there are consulted people in order to shape the decision-making situation. The decision-making process and its quality are influenced by skills, preparation and implication of the decider. As a result, to have a well-founded decision, any decision-making process must purchase, process and interpret a more and more volume of information, in a shorter time.

\section{REFERENCES}

1. Bragă Viorina (2010), Contabilitatea managerială, Piteşti: Paralela 45.

2. Tascovici Daliana, Dragomir Robert, Isbăşoiu Eliza, \& Zărnescu Odi Mihaela (2013), New Directions For The Costs Of Evaluation, Annals of Spiru Haret University, Economic Series, vol. 4(13), issue 1, p. 53-58.

3. Tofan Adina Cezarina (2008), Modele de date multidimensionale pentru previzionarea, calculul și analiza costurilor, Tribuna Economică, no. 16.

4. Tofan Adina Cezarina (2008), Proiectarea depozitelor de date pentru previzionarea, calculul şi analiza costurilor, Tribuna Economică, no. 36.

5. Tofan Adina Cezarina (2008), Sisteme informatice pentru management, Revista MarketingManagement, Asociaţia Română de Marketing, no. 1-2, Bucureşti.

6. Zaman Gheorghe, \& Gherasim Zenovic (2010), Information Technology and communication $(I T \& C)$ and Research and Development $(R \& D)$, outstanding factors of the post-crisis economic recovery, Annals of Spiru Haret University, Economic Series, vol. 1(10), issue 3, p. 11-28. 